\title{
Short-term ingestion of chlorogenic or caffeic acids decreases zinc but not copper absorption in rats, utilization of stable isotopes and inductively-coupled plasma mass spectrometry technique
}

\author{
Charles Coudray ${ }^{1}$, Carole Bousset ${ }^{1}$, Jean C. Tressol ${ }^{1}$, Denise Pépin ${ }^{2}$ and Yves Rayssiguier ${ }^{1}$ \\ ${ }^{1}$ Centre de Recherche en Nutrition Humaine d'Auvergne, Laboratoire Maladies Métaboliques et Micronutriments, \\ INRA de Clermont-Ferrand/Theix, 63122 Saint Genès Champanelle, France \\ ${ }^{2}$ Laboratoire d'hydrologie, Institut Louise Blanquet, Faculté de Pharmacie, Université d'Auvergne, \\ Clermont-Ferrand, France
}

(Received 20 January 1998 - Revised 17 July 1998 - Accepted 21 July 1998)

\begin{abstract}
The amount of dietary trace elements absorbed from a meal depends, among other factors, on the quantities of certain minor plant constituents present in the meal. These substances can act as ligands and bind trace elements in the digestive tract in available or unavailable forms for absorption. The present study was designed to investigate the extent to which different polyphenols (PP) may influence $\mathrm{Zn}$ and $\mathrm{Cu}$ absorption in rats. Different $\mathrm{PP}$ of nutritional interest (chlorogenic acid, caffeic acid, catechin and rutin) were studied using meals extrinsicallylabelled with stable isotopes ${ }^{67} \mathrm{Zn}$ and ${ }^{65} \mathrm{Cu}$. Male Wistar rats were fed on a non-labelled semisynthetic diet containing $(\mathrm{mg} / \mathrm{kg}) 38 \mathrm{Fe}, 35 \mathrm{Zn}$ and $7.5 \mathrm{Cu}$ for $8 \mathrm{~d}$. PP were dissolved in dimethyl sulfoxide as the solvent and added to the meal at $1 \mathrm{~g} / \mathrm{kg}$ during $3 \mathrm{~d}$ before isotope administration and until the end of the experiment (a further $3 \mathrm{~d}$ ). The control group received the dimethyl sulfoxide only. After overnight food deprivation, rats were fed on the labelled test meals $(4 \mathrm{~g}$ diet $+0.1 \mathrm{mg}{ }^{67} \mathrm{Zn}$ and $0.1 \mathrm{mg}{ }^{65} \mathrm{Cu}$ ) with $0.5 \mathrm{mg}$ Dy as a faecal marker. Faeces and urine pools were collected for $3 \mathrm{~d}$ and analysed for ${ }^{67} \mathrm{Zn}$ and ${ }^{65} \mathrm{Cu}$ isotopic enrichment using the inductivelycoupled plasma mass spectrometry technique. Zn absorption was significantly less in rats fed on chlorogenic acid or caffeic acid than in the control group. Catechin ingestion non-significantly inhibited ${ }^{67} \mathrm{Zn}$ absorption. However, the PP studied were without effect on $\mathrm{Cu}$ absorption. The study illustrates the effect of metal-binding phenolic compounds on mineral nutrition in the rat, and the possible importance of the effects of different foods rich in these compounds on mineral absorption in man.
\end{abstract}

Polyphenols: Cu absorption: $\mathrm{Zn}$ absorption: Isotope technique

The establishment of human requirements for essential trace elements necessarily includes knowledge of the factors affecting trace element availability for absorption. Although it is recognized that $\mathrm{Zn}$ and $\mathrm{Cu}$ bioavailability from many plant sources is generally low, the responsible factors have not been clearly identified. Polyphenols (PP), a wide and complex group of substances, are naturally present in foods of vegetable origin and constitute part of the human diet. Their intake can range between 0.5 and $2 \mathrm{~g} / \mathrm{d}$ (Reddy et al. 1985). Several in vitro and animal studies have demonstrated that PP have antioxidant activities and play a potential role in cardiovascular diseases and cancer prevention (Cook \& Samman, 1996; Hertog \& Hollman, 1996), and there are recommendations to increase their daily intake.
However, many studies in animals and man have shown that these compounds or PP-rich foods dramatically inhibited non-haem-Fe absorption (Hurrell, 1990; Tuntawiroon et al. 1991). This inhibitory effect seems to be due to the chelation capacity of these compounds relative to metal ions (Brune et al. 1989). Many popular beverages such as tea, coffee and wine contain high levels of PP. The inhibitory effect of tea and red wine on Fe absorption appears to be related to the total amount of PP consumed (Disler et al. 1975; Morck et al. 1983; Cook et al. 1995). The inhibitory action of coffee on Fe absorption appears to be due to chlorogenic acid (Gabrielli \& De Sandre, 1995). The effect of PP on Zn and $\mathrm{Cu}$ absorption has received little attention, although the available information suggests that such compounds can

\footnotetext{
Abbreviations: ${ }^{65} \mathrm{Cu} *{ }^{65} \mathrm{Cu}$ derived only from administered isotope; ICP/MS, inductively-coupled plasma mass spectrometry; $\mathrm{PP}$, polyphenols; ${ }^{67} \mathrm{Zn} *$, ${ }^{67} \mathrm{Zn}$ derived only from administered isotope.

*Corresponding author: Dr Charles Coudray, fax +33 047362 46 38, email charles.coudray@clermont.inra.fr
} 
chelate these elements and should affect their availability for absorption (McDonald et al. 1996). Since $\mathrm{Zn}$ and $\mathrm{Cu}$ belong to the transition group of elements as does Fe, it is possible that PP can also modify their absorption. In a human study, Ganji \& Kies (1994) showed that tea consumption resulted in a small but non-significantly adverse effect on $\mathrm{Zn}$ balance in human subjects $(-7 \%)$. However, Record et al. (1996), using the chemical-balance technique, have failed to show any effect of teas on the absorption of $\mathrm{Fe}, \mathrm{Cu}$ and $\mathrm{Zn}$ in rats. The stable-isotope approach is now recognized to be an excellent tool for mineral bioavailability studies (Janghorbani \& Ting, 1990; Coudray \& Fairweather-Tait, 1998). Based on this principle, our study was conducted to assess potential inhibitory effects of different PP of nutritional interest (chlorogenic and caffeic acids, catechin and rutin) on $\mathrm{Zn}$ and $\mathrm{Cu}$ absorption in rats fed on meals extrinsically labelled with stable isotopes ${ }^{67} \mathrm{Zn}$ and ${ }^{65} \mathrm{Cu}$.

\section{Materials and methods}

\section{Reagents and materials}

Enriched ${ }^{67} \mathrm{Zn}(94.6 \%)$ and ${ }^{65} \mathrm{Cu}(99.6 \%)$ isotopes as oxides were obtained from Euriso-top (Saint Aubin, France). Suprapure grade $\mathrm{HNO}_{3}, \mathrm{HCl}$ and $\mathrm{H}_{2} \mathrm{O}_{2}$, pyridine, hexane, dimethyl sulfoxide, and $\mathrm{Zn}, \mathrm{Cu}$, Dy and In standard solutions $(1 \mathrm{~g} / \mathrm{l})$ were obtained from Merck (Darmstadt, Germany). Chlorogenic acid, caffeic acid, catechin and rutin were obtained from Sigma (Saint Quentin Fallavier, France). Trifluoroacetylacetone $(980 \mathrm{ml} / \mathrm{l})$ was purchased from Aldrich-Chimie (Saint Quentin Fallavier, France). All other chemicals were of the highest quality available, and demineralized water was used throughout.

The inductively-coupled plasma mass spectrometer (ICP/MS) used in our study for isotopic-ratio measurements was a Plasmaquad II system (Fisons Instruments, Manchester, UK), equipped with a Meinhard nebulizer. The atomic absorption spectrometer Perkin Elmer 560 (Perkin Elmer, St-Quentin en Yvelines, France) was used for total $\mathrm{Zn}$ and $\mathrm{Cu}$ measurements.

\section{Animals and diet}

Male Wistar rats weighing 200 (SE 5) g were used. They were derived from the colony of laboratory animals of the National Institute of Agronomic Research (INRA of Clermont-Ferrand/Theix, France). The rats were housed under conditions of constant temperature $\left(20-22^{\circ}\right)$, humidity $(45-50 \%)$ and a standard dark cycle $(20.00-08.00$ hours). The rats were maintained in compliance with the guidelines formulated by the European Union (EEC, 1986) for the use of experimental animals. Rats first went through an adaptation period of $8 \mathrm{~d}$ with free access to a semi-synthetic diet and demineralized water. The nonlabelled diet contained $(\mathrm{g} / \mathrm{kg})$ : casein 200 , wheat starch 650, maize oil 50, fibre (cellulose) 50, mineral mixture (American Institute of Nutrition, 1977) 35, vitamin mixture (American Institute of Nutrition, 1977) 10, DL-methionine 3 , choline bitartarate $2 . \mathrm{Fe}, \mathrm{Zn}$ and $\mathrm{Cu}$ levels in this diet were 38,35 and $7.5 \mathrm{mg} / \mathrm{kg}$ dry weight respectively.
Powdered diet $(100 \mathrm{~g})$ was mixed with $100 \mathrm{ml}$ demineralized water to form a semi-liquid food prepared on site.

\section{Stable-isotope preparation}

The isotope analysis of the enriched ${ }^{67} \mathrm{Zn}$ as $\mathrm{ZnO}$ yielded the following values (atom \%): ${ }^{64} \mathrm{Zn} 1 \cdot 11,{ }^{66} \mathrm{Zn} 1 \cdot 95,{ }^{67} \mathrm{Zn}$ 94.60, ${ }^{68} \mathrm{Zn} 2 \cdot 28,{ }^{70} \mathrm{Zn} \mathrm{0.05}$. Enriched $\mathrm{ZnO}(25 \mathrm{mg} ; 20 \mathrm{mg}$ $\mathrm{Zn}$ ) was first moistened with $1 \mathrm{ml}$ demineralized water, and then $1 \mathrm{ml} 12 \mathrm{M}-\mathrm{HCl}$ was added to transform the oxide into soluble $\mathrm{ZnCl}_{2}$. The solution was then diluted with $7.5 \mathrm{ml}$ demineralized water to give a concentration of $2 \mathrm{~g}{ }^{67} \mathrm{Zn} / 1$. The isotope analysis of the enriched ${ }^{65} \mathrm{Cu}$ as $\mathrm{CuO}$ yielded the following values (atom \%): ${ }^{63} \mathrm{Cu} 0 \cdot 39,{ }^{65} \mathrm{Cu} 99 \cdot 61$. Enriched $\mathrm{CuO}(87.6 \mathrm{mg} ; 70 \mathrm{mg} \mathrm{Cu})$ was first moistened with $1 \mathrm{ml}$ demineralized water, and then $1 \mathrm{ml} 12 \mathrm{M}-\mathrm{HCl}$ (suprapure grade) was added and heated at $80^{\circ}$ for $2 \mathrm{~h}$ to transform the oxide into the soluble $\mathrm{CuCl}_{2}$. The solution was then diluted with $8 \mathrm{ml}$ demineralized water to give a concentration of $7 \mathrm{~g}{ }^{65} \mathrm{Cu} / \mathrm{l}$. The abundance and the concentrations of ${ }^{67} \mathrm{Zn}$ and ${ }^{65} \mathrm{Cu}$ isotopes in these solutions were checked by ICP/MS before they were used.

\section{Preliminary study: validation of faecal marker use and choice of stable-isotope doses and method of administration}

In this first study, we investigated the isotope doses of $0.15 \mathrm{mg}{ }^{67} \mathrm{Zn}$ and $0.15 \mathrm{mg}{ }^{65} \mathrm{Cu}$. Dy $(1 \mathrm{mg})$ was used as the faecal marker. The choice of these doses was based on usual daily intake of $\mathrm{Zn}$ and $\mathrm{Cu}$ and their mean fractional absorption, as well as on the natural abundance of investigated isotopes and the degree of anticipated isotope enrichments in the waste product studied (faeces and urine). After an adaptation period to the semi-synthetic diet, twelve rats were divided into two groups and placed in individual metabolism cages. After a $16 \mathrm{~h}$ fast group 1 received the isotope dose orally with Dy $(2 \mathrm{ml})$, and group 2 received the isotope dose mixed with a small meal $(4 \mathrm{~g}$ semi-liquid non-labelled diet $+4 \mathrm{ml}$ isotope and Dy solution). The small meal was prepared $16 \mathrm{~h}$ before isotope administration to allow isotopes to equilibrate with the naturally-occurring elements in the semi-liquid meal. Faeces and urine samples were collected daily before and for five successive days after isotope administration.

\section{Polyphenol study: acute effect of polyphenol ingestion on zinc and copper absorption}

The PP-containing diets and test meals were prepared as follows. The PP investigated in the present study were chlorogenic acid, caffeic acid, catechin and rutin. Since their solubility in water is low the PP were dissolved in dimethyl sulfoxide at a concentration of $250 \mathrm{~g} / \mathrm{l}$, and then diluted with water to obtain a final concentration of $1 \mathrm{~g} / \mathrm{l}$. These solutions were used to prepare the semi-liquid food for the PP-tested groups; these were prepared on site $(100 \mathrm{~g}$ diet $+100 \mathrm{ml}$ PP solution) and offered throughout the experiment. To prepare the test labelled meals, $2 \mathrm{ml}$ PP solution $(4 \mathrm{mg} P P)$ and $2 \mathrm{ml}$ of a solution containing ${ }^{67} \mathrm{Zn}$ $(0.1 \mathrm{mg}),{ }^{65} \mathrm{Cu}(0.1 \mathrm{mg})$ and Dy $(0.5 \mathrm{mg})$ were mixed with $4 \mathrm{~g}$ semi-liquid non-labelled diet. Added isotopes were then 
allowed to equilibrate with the naturally-occurring $\mathrm{Zn}$ and $\mathrm{Cu}$ in the semi-liquid diet overnight before being administered. Accurate concentrations of isotopes in this solution were determined by ICP/MS.

\section{Experimental protocol}

After an $8 \mathrm{~d}$ adaptation period to the non-labelled semisynthetic diet, the rats were assigned randomly to four PP groups of eight rats each, and to a control group of ten rats. The diet of the control group contained the same amount of dimethyl sulfoxide as that used as solvent in the other groups (i.e. dimethyl sulfoxide only). The rats then received their respective diets for $3 \mathrm{~d}$ before isotope administration. The day before isotope administration, the animals were placed in individual metabolism cages, and $24 \mathrm{~h}$ faecal and urine samples (non-labelled samples) were collected from each animal. At 06.00 hours, test labelled meals were offered to the $16 \mathrm{~h}$ fasted rats for $2 \mathrm{~h}$ in the dark. The unconsumed food was then recovered and accurately weighed. Rats then continued to receive the PP-containing non-labelled diets until the end of the experiment. Faeces were collected quantitatively for the $3 \mathrm{~d}$ after isotope administration and pooled. Urine was collected over two periods (0-36 and 36-72 h) after isotope administration.

\section{Sample treatment and analysis}

Individual faeces collected before and after isotope administration were freeze-dried, powdered and sub-samples $(0.25 \mathrm{~g})$ were ashed at $500^{\circ}$ for $10 \mathrm{~h}$. The ashes were dissolved in $0.2 \mathrm{ml} 14 \mathrm{M}-\mathrm{HNO}_{3}$ and heated for $2 \mathrm{~h}$ at $100^{\circ}$ on a hot plate, and diluted appropriately with $0 \cdot 14 \mathrm{M}-\mathrm{HNO}_{3}$. $\mathrm{Zn}$ and $\mathrm{Cu}$ isotope ratios and Dy concentration were determined by ICP/MS using $\mathrm{Zn}, \mathrm{Cu}$ and Dy solutions as internal standards. The concentrations of $\mathrm{Cu}, \mathrm{Zn}$ and $\mathrm{Dy}$ in final solutions of faeces for ICP/MS measurements was about 200,40 and $20 \mathrm{pg} / \mathrm{l}$ respectively. In was used as the external standard for faecal Dy determination. Total $\mathrm{Zn}$ $(213.8 \mathrm{~nm})$ and $\mathrm{Cu}(324.7 \mathrm{~nm})$ were determined by flame atomic absorption spectrometry (Perkin Elmer 560), using seronorm serum (Nycomed, Oslo, Norway) as quality control, as previously described (Arnaud et al. 1993).

Urine volume was determined and $10 \mathrm{ml}$ urine was acidified with $0 \cdot 1 \mathrm{ml} 14 \mathrm{M}-\mathrm{HNO}_{3}$. Isotope-ratio measurement on urine samples was performed as previously described (Veillon \& Patterson, 1996). Briefly, an appropriate volume of urine $(2.5 \mathrm{ml})$ was dried and ashed at $500^{\circ}$ for $10 \mathrm{~h}$. The ashed sample was then dissolved in $0.2 \mathrm{ml}$ $14 \mathrm{M}-\mathrm{HNO}_{3}$ and $0.1 \mathrm{ml} \mathrm{H}_{2} \mathrm{O}_{2}(350 \mathrm{ml} / \mathrm{l})$ and heated to dryness. This procedure was repeated three times to obtain a white residue. $\mathrm{Zn}$ and $\mathrm{Cu}$ was then complexed with trifluoroacetylacetone in the presence of pyridine ( $\mathrm{pH} 5.5)$ and the complexes were extracted with hexane. The hexane extract was removed and evaporated to dryness, and the dry residue was taken up in $0.2 \mathrm{ml} 14 \mathrm{M}-\mathrm{HNO}_{3}$ and made up to $5 \mathrm{ml}$ with demineralized water. $\mathrm{Zn}$ and $\mathrm{Cu}$ isotope ratios were then determined by ICP/MS. The concentration of $\mathrm{Cu}$ and $\mathrm{Zn}$ in final solutions of urine for ICP/MS measurements was about 150 and $50 \mathrm{pg} / 1$ respectively. Total $\mathrm{Zn}(213.8 \mathrm{~nm})$ and $\mathrm{Cu}(324.7 \mathrm{~nm})$ were determined by flame atomic absorption spectrometry (Perkin Elmer 560), using seronorm urine (Nycomed) as quality control, as previously described (Arnaud et al. 1993).

The mass spectrometer settings and plasma conditions were optimized with a solution of $10 \mu \mathrm{g} \mathrm{In} / 1$ as external standard, with the instrument operating conditions as follows: radio frequency generator $27.12 \mathrm{MHz}$, forward radio frequency power $1350 \mathrm{~W}$, reflected radio-frequency power $<3 \mathrm{~W}$, outer Ar flow-rate 14 litres/min, intermediate Ar flow-rate 0.7 litre/min, nebulizer Ar flow-rate 0.76 litre/ min, mass resolution $0.9 \mathrm{Da}$ at $10 \%$ of peak height. Data collection variables were as follows: total replicates per integration 5, signal integration time per replicate $40 \mathrm{~s}$, dwell time per sweep $20.4 \mathrm{~ms}$, scanning mode: peak hopping five points per peak, sample uptake rate $0.6 \mathrm{ml} / \mathrm{min}$.

\section{Calculations}

$\mathrm{Zn}$ has five stable isotopes with the following natural abundance (\%): ${ }^{64} \mathrm{Zn} 48 \cdot 6,{ }^{66} \mathrm{Zn} 27 \cdot 9,{ }^{67} \mathrm{Zn} 4 \cdot 1,{ }^{68} \mathrm{Zn} 18 \cdot 8$, ${ }^{70} \mathrm{Zn} 0 \cdot 6$; $\mathrm{Cu}$ has only two stable isotopes with the following natural abundance (\%): ${ }^{63} \mathrm{Cu} 69 \cdot 2,{ }^{65} \mathrm{Cu} 30 \cdot 8$ (De Bièvre $\&$ Taylor, 1993). Isotope percentage enrichment for ${ }^{67} \mathrm{Zn}$ or ${ }^{65} \mathrm{Cu}$ in faeces or urine was obtained from the following equation: $100 \times(($ measured isotope ratio-baseline isotope ratio)/baseline isotope ratio). Baseline isotope ratios are obtained by the instrument for samples before isotope administration and these should be similar to natural ratios which are as follows: ${ }^{67} \mathrm{Zn}:{ }^{66} \mathrm{Zn} 0 \cdot 14695$ and ${ }^{65} \mathrm{Cu}:{ }^{63} \mathrm{Cu}$ 0.44509).

Total faecal unabsorbed or urinary excreted isotopes were determined as previously described for $\mathrm{Mg}$ isotopes (Coudray et al. 1997): total ${ }^{67} \mathrm{Zn}$ or ${ }^{65} \mathrm{Cu}$ derived only from the administered isotope $\left({ }^{67} \mathrm{Zn} *\right.$ and ${ }^{65} \mathrm{Cu}^{*}$ respectively $)=($ total faecal or urine mineral $\times($ measured isotope ratio - baseline isotope ratio) $) /(\mathrm{Y}+($ measured isotope ratio - baseline isotope ratio)), where the isotope ratio is ${ }^{67} \mathrm{Zn}:{ }^{66} \mathrm{Zn}$ for $\mathrm{Zn}$ and ${ }^{65} \mathrm{Cu}{ }^{63} \mathrm{Cu}$ for $\mathrm{Cu}$, Y is 3.584 for $\mathrm{Zn}$ (the reciprocal of $0 \cdot 279$ to convert ${ }^{66} \mathrm{Zn}$ quantity to total $\mathrm{Zn}$ ), and $\mathrm{Y}$ is 1.4451 for $\mathrm{Cu}$ (the reciprocal of 0.692 to convert ${ }^{63} \mathrm{Cu}$ quantity to total $\mathrm{Cu}$ ). Total faecal and urinary $\mathrm{Zn}$ or $\mathrm{Cu}(\mathrm{mg})$ were determined by atomic absorption spectrometry.

The previously mentioned formula is obtained as follows (e.g. for $\mathrm{Cu}$ ):

$$
\begin{gathered}
\text { measured }{ }^{65} \mathrm{Cu}:{ }^{63} \mathrm{Cu}=\text { baseline }{ }^{65} \mathrm{Cu}:{ }^{63} \mathrm{Cu}+{ }^{65} \mathrm{Cu}^{*}:{ }^{63} \mathrm{Cu}, \\
\text { total } \mathrm{Cu}=\left(\text { natural } \mathrm{Cu}+{ }^{65} \mathrm{Cu}^{*}\right), \\
\text { natural } \mathrm{Cu}={ }^{63} \mathrm{Cu} \times\left(1 /{ }^{63} \mathrm{Cu}\right. \text { natural abundance) } \\
={ }^{63} \mathrm{Cu} \times 1.4451 .
\end{gathered}
$$

Equation 2 becomes:

$$
\text { total } \mathrm{Cu}=\left({ }^{63} \mathrm{Cu} \times 1.4451+{ }^{65} \mathrm{Cu}^{*}\right),
$$

thus,

$$
{ }^{65} \mathrm{Cu}^{*}=\text { total } \mathrm{Cu}-\left({ }^{63} \mathrm{Cu} \times 1.4451\right) .
$$


From equation 1,

measured ${ }^{65} \mathrm{Cu}:{ }^{63} \mathrm{Cu}-$ baseline ${ }^{65} \mathrm{Cu}:{ }^{63} \mathrm{Cu}={ }^{65} \mathrm{Cu}^{*}:{ }^{63} \mathrm{Cu}$.

Equation 6 becomes:

$$
\begin{gathered}
\text { (measured } \left.{ }^{65} \mathrm{Cu}:{ }^{63} \mathrm{Cu}-\text { baseline }{ }^{65} \mathrm{Cu}:{ }^{63} \mathrm{Cu}\right) / 1 \\
={ }^{65} \mathrm{Cu}^{*}:{ }^{63} \mathrm{Cu} .
\end{gathered}
$$

Equation 7 becomes:

${ }^{63} \mathrm{Cu}={ }^{65} \mathrm{Cu}^{*} /\left(\right.$ measured ${ }^{65} \mathrm{Cu}:{ }^{63} \mathrm{Cu}$ - baseline ${ }^{65} \mathrm{Cu}:{ }^{63} \mathrm{Cu}$ ).

From equations 5 and 8:

$$
\begin{gathered}
{ }^{65} \mathrm{Cu}^{*}=\text { total } \mathrm{Cu}-\left(1.4451 \times{ }^{65} \mathrm{Cu}^{*} /\right. \\
\text { (measured } \left.\left.{ }^{65} \mathrm{Cu}:{ }^{63} \mathrm{Cu} \text { - baseline }{ }^{65} \mathrm{Cu}:{ }^{63} \mathrm{Cu}\right)\right) .
\end{gathered}
$$

Multiplying equation 9 by: measured ${ }^{65} \mathrm{Cu}:{ }^{63} \mathrm{Cu}-$ baseline ${ }^{65} \mathrm{Cu}:{ }^{63} \mathrm{Cu}$ gives:

$$
\begin{gathered}
{ }^{65} \mathrm{Cu}^{*} \times\left(\text { measured }{ }^{65} \mathrm{Cu}:{ }^{63} \mathrm{Cu}-\text { baseline }{ }^{65} \mathrm{Cu}:{ }^{63} \mathrm{Cu}\right) \\
=\text { total } \mathrm{Cu} \times\left(\text { measured }{ }^{65} \mathrm{Cu}:{ }^{63} \mathrm{Cu}-\text { baseline }{ }^{65} \mathrm{Cu}:{ }^{63} \mathrm{Cu}\right) \\
-\left(1.4451 \times{ }^{65} \mathrm{Cu}^{*}\right) .
\end{gathered}
$$

Then,

$$
\begin{gathered}
{ }^{65} \mathrm{Cu}^{*} \times\left(\text { measured }{ }^{65} \mathrm{Cu}:{ }^{63} \mathrm{Cu}-\text { baseline }{ }^{65} \mathrm{Cu}:{ }^{63} \mathrm{Cu}\right) \\
+\left(1.4451 \times{ }^{65} \mathrm{Cu}^{*}\right) \\
=\text { total } \mathrm{Cu} \times\left(\text { measured }{ }^{65} \mathrm{Cu}:{ }^{63} \mathrm{Cu}\right. \\
\left.- \text { baseline }{ }^{65} \mathrm{Cu}:{ }^{63} \mathrm{Cu}\right) .
\end{gathered}
$$

Rearranging equation 11 ,

$$
\begin{gathered}
{ }^{65} \mathrm{Cu}^{*} \times\left(1 \cdot 4451+\left(\text { measured }{ }^{65} \mathrm{Cu}:{ }^{63} \mathrm{Cu}\right.\right. \\
\left.\left.- \text { baseline }{ }^{65} \mathrm{Cu}:{ }^{63} \mathrm{Cu}\right)\right)=\text { total } \mathrm{Cu} \\
\times\left(\text { measured }{ }^{65} \mathrm{Cu}:{ }^{63} \mathrm{Cu} \text { - baseline }{ }^{65} \mathrm{Cu}:{ }^{63} \mathrm{Cu}\right) .
\end{gathered}
$$

Thus, our formula is:

$$
\begin{gathered}
{ }^{65} \mathrm{Cu}^{*}=\left(\text { total } \mathrm{Cu} \times\left(\text { measured }{ }^{65} \mathrm{Cu}:{ }^{63} \mathrm{Cu}\right.\right. \\
\left.\left.- \text { baseline }{ }^{65} \mathrm{Cu}:{ }^{63} \mathrm{Cu}\right)\right) /\left(1 \cdot 4451+\left(\text { measured }{ }^{65} \mathrm{Cu}:{ }^{63} \mathrm{Cu}\right.\right. \\
\left.\left.- \text { baseline }{ }^{65} \mathrm{Cu}:{ }^{63} \mathrm{Cu}\right)\right) .
\end{gathered}
$$

The same steps can be followed to obtain the formula for ${ }^{67} \mathrm{Zn}^{*}$.

${ }^{67} \mathrm{Zn}$ or ${ }^{65} \mathrm{Cu}$ apparent absorption, based on faecal isotope enrichment, was calculated from the following formula: $100 \times(($ administered isotope - unabsorbed isotope excreted in the faeces)/administered isotope). Correction of absorption for percentage faecal marker recovery was made according to the following equation: corrected absorption $=100 \times($ administered isotope $-($ unabsorbed isotope $/$ percentage faecal marker recovery)/administered isotope). Percentage faecal marker recovery was calculated from the following formula: (administered Dy - faecal excreted Dy)/ (administered Dy).

\section{Statistical analysis}

Standard procedures were used to calculate means with their standard errors. Throughout the preliminary study, the statistical significance of differences $(P<0.05)$ between means was calculated by using Student's $t$ test. In the PP study, results from five groups were compared by ANOVA using the GLM procedure of Statistical Analysis Systems (1989) according to the factorial model. The least-squares mean statement was used to calculate the adjusted means. For each experimental diet the data are presented as adjusted means with their standard errors because the numbers of animals were not identical for the five groups. The ANOVA test was followed by a Duncan multiple range test. Differences between groups were considered as significant when $P<0.05$.

\section{Results}

\section{Analytical performances}

The isotope-ratio measurements were performed using an ICP/MS instrument which permitted within- and betweenrun percentage residual standard deviations as follows: on standard solutions ${ }^{67} \mathrm{Zn}:{ }^{66} \mathrm{Zn} 0 \cdot 51,0 \cdot 89,{ }^{65} \mathrm{Cu}:{ }^{63} \mathrm{Cu}$ $0.42,0.76$; on faecal mineralisate solutions ${ }^{67} \mathrm{Zn}:{ }^{66} \mathrm{Zn}$ $0.68,1.24,{ }^{65} \mathrm{Cu}:{ }^{63} \mathrm{Cu} \quad 0.61,0.97 ;$ on urine extracts ${ }^{67} \mathrm{Zn}:{ }^{66} \mathrm{Zn} 0.63,1 \cdot 14,{ }^{65} \mathrm{Cu}:{ }^{63} \mathrm{Cu} \mathrm{0.56,0.92}$. The withinand between-run percentage residual standard deviations for Dy determinations were 2.1 and 4.9 respectively. Total $\mathrm{Zn}$ and $\mathrm{Cu}$ were analysed by atomic absorption spectrometry in faeces with the following within- and between-run percentage residual standard deviations: $3 \cdot 4$ and $6 \cdot 1$ for $\mathrm{Zn}$ and 3.8 and 5.2 for $\mathrm{Cu}$ respectively. The corresponding values (\%) for urine analysis were as follows: 2.9 and 5.2 for $\mathrm{Zn}$ and $3 \cdot 3$ and $5 \cdot 8$ for $\mathrm{Cu}$ determinations.

\section{Preliminary study}

The results of this preliminary study show that the kinetics of faecal Dy excretion closely paralleled those of ${ }^{67} \mathrm{Zn}$ and ${ }^{65} \mathrm{Cu}$ for both methods of administration (Fig. 1). Dy faecal excretion was shown to be nearly complete in most of rats $(>95 \%)$, but not in three of them (Table 1). The percentage recovery of Dy was only 67 and 66.8 for two rats in the orally-administered group, and was 83.4 for one rat in the premixed-isotope group. The measured absorption of ${ }^{67} \mathrm{Zn}$ and ${ }^{65} \mathrm{Cu}$ for these rats was very high, but it reached the mean values when it was corrected to the percentage recovery of faecal marker (Table 1). As shown in Fig. 2, the majority of the unabsorbed isotopes $\left({ }^{67} \mathrm{Zn}\right.$ and $\left.{ }^{65} \mathrm{Cu}\right)$ was excreted within the $48 \mathrm{~h}$ after isotope administration (>95\% and $>93 \%$ for the two methods of isotope administration. The administration of $0.15 \mathrm{mg}{ }^{67} \mathrm{Zn}$ or ${ }^{65} \mathrm{Cu}$ resulted in a large faecal isotope enrichment in the first $2 \mathrm{~d}$ in both rat groups. Moreover, more than 98 and $99 \%$ of unabsorbed isotopes were excreted during $3 \mathrm{~d}$ after isotope administration. The faecal isotope enrichments of ${ }^{67} \mathrm{Zn}$ and ${ }^{65} \mathrm{Cu}$ measured in the $3 \mathrm{~d}$ faeces pool were at least as high as $100 \%$ for each isotope for both methods of administration. The enrichment of ${ }^{67} \mathrm{Zn}$ and ${ }^{65} \mathrm{Cu}$ in the $0-24 \mathrm{~h}$ pooled urine samples averaged about 22 and $55 \%$ respectively. This 

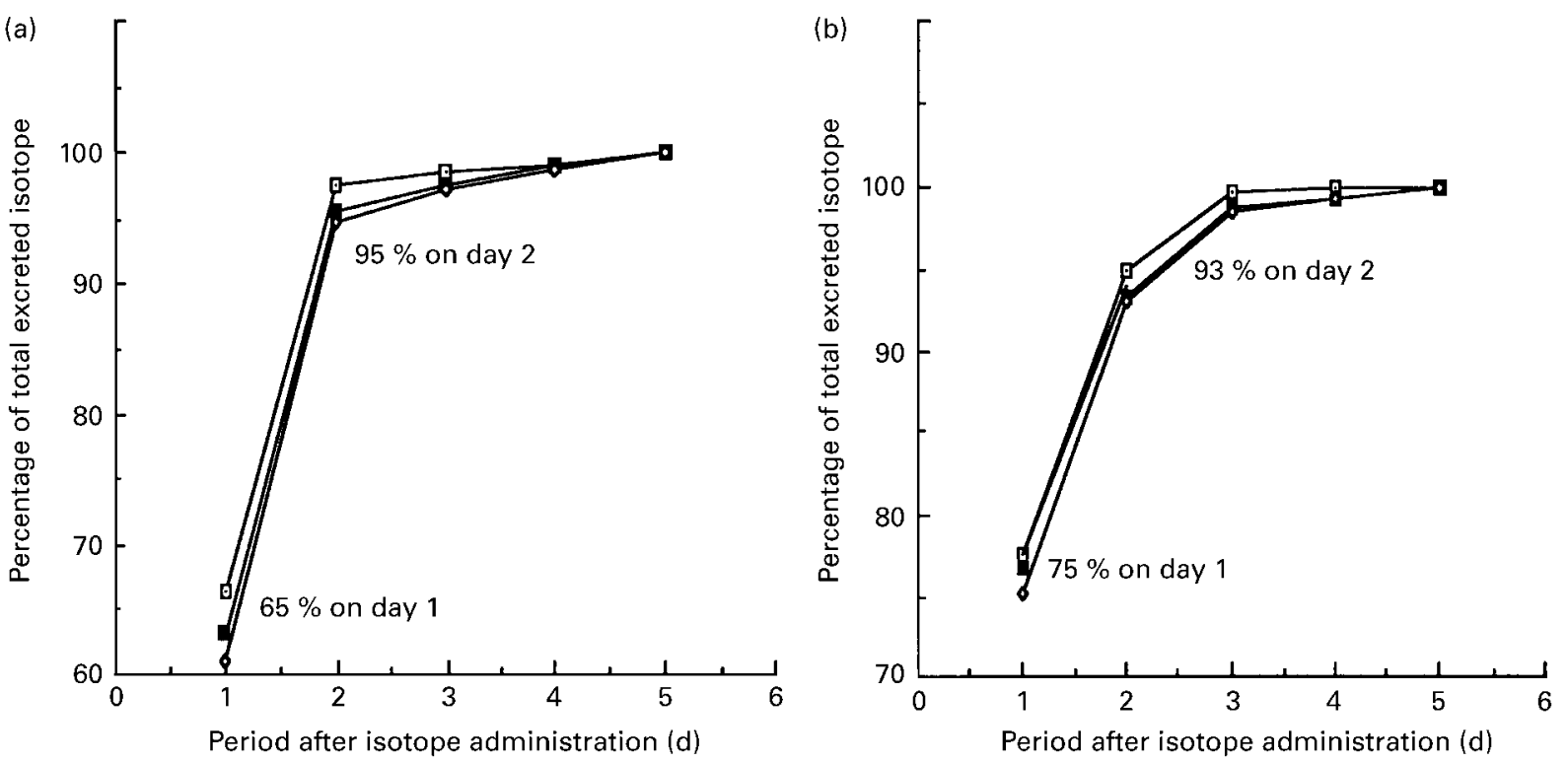

Fig. 1. Faecal excretion patterns of faecal marker (dysprosium; $\square)$ and unabsorbed isotopes $\left({ }^{67} \mathrm{Zn}(\boldsymbol{\square})\right.$ and $\left.{ }^{65} \mathrm{Cu}(\diamond)\right)$, expressed as cumulative percentage of total excreted element, in rats given $0.15 \mathrm{mg}{ }^{67} \mathrm{Zn}(2.24 \mu \mathrm{mol})$ and $0.15 \mathrm{mg}{ }^{65} \mathrm{Cu}(2.31 \mu \mathrm{mol})$ and $1.0 \mathrm{mg}$ dysprosium $(6.15 \mu \mathrm{mol})$ either orally (a) or premixed with a small meal (b). Pooled faeces for each day were lyophilized, powdered and a subsample was mineralized and analysed by inductively-coupled plasma mass spectrometry for determining dysprosium concentration and zinc and copper enrichments. Total zinc and copper levels were determined by atomic absorption spectrometry. For details of procedures, see pp. 576-577.

shows clearly that isotope doses were sufficient and the amount of unabsorbed isotopes in a $3 \mathrm{~d}$ faeces pool is appropriate for determining apparent absorption of $\mathrm{Zn}$ and $\mathrm{Cu}$ in rats. There was no statistically significant difference in ${ }^{67} \mathrm{Zn}$ absorption between the two methods of administration. However, our results indicate that the ${ }^{65} \mathrm{Cu}$ absorption was more efficient when the isotope was given orally than when premixed with the diet. Unabsorbed isotopes were nearly completely excreted within $3 \mathrm{~d}(>99 \%)$ when isotopes were premixed with the diet. We also obtained more reliable results when isotopes were given premixed with the diet, with lesser variability between rats $(\mathrm{CV}<10 \%)$. Since isotope administration by premixing with the diet is a more physiological process and permits a necessary equilibrium between the added isotopes and the naturally-occurring minerals of the diet, we used this method in our PP study.

Table 1. Individual values for percentage recovery of the faecal marker (dysprosium) and measured and corrected values for intestinal absorption of ${ }^{67} \mathrm{Zn}$ and ${ }^{65} \mathrm{Cu}$ stable isotopes given orally or premixed with a small meal to rats ${ }^{\star}$

\begin{tabular}{|c|c|c|c|c|c|c|}
\hline \multirow{2}{*}{$\begin{array}{l}\text { Procedure for isotope } \\
\text { administration }\end{array}$} & \multirow[b]{2}{*}{ Rat no. } & \multicolumn{2}{|c|}{$\begin{array}{l}\text { Measured absorption } \\
(\%)\end{array}$} & \multirow[b]{2}{*}{ Dy recovery (\%) } & \multicolumn{2}{|c|}{$\begin{array}{c}\text { Corrected absorption } \\
(\%)\end{array}$} \\
\hline & & ${ }^{65} \mathrm{Cu}$ & ${ }^{67} \mathrm{Zn}$ & & ${ }^{65} \mathrm{Cu}$ & ${ }^{67} \mathrm{Zn}$ \\
\hline Oral & $\begin{array}{l}1 \\
2 \\
3 \\
4 \\
5 \\
6 \\
\text { Mean } \\
\text { SE }\end{array}$ & $\begin{array}{c}39.8 \\
16.4 \\
19.0 \\
44.7 \\
24.0 \\
18.8 \\
27.1 \\
4.93\end{array}$ & $\begin{array}{c}42.1 \\
19.8 \\
18.6 \\
46.6 \\
19.9 \\
23.0 \\
28.3 \\
5.13\end{array}$ & $\begin{array}{c}67.0 \\
97 \cdot 2 \\
98.9 \\
66.8 \\
92.1 \\
93.6 \\
85.9 \\
6.10\end{array}$ & $\begin{array}{c}14.0 \\
17.9 \\
21.8 \\
21.1 \\
21.3 \\
17.2 \\
18.9 \\
1.25\end{array}$ & $\begin{array}{c}17.3 \\
21.2 \\
21.4 \\
23.7 \\
17.0 \\
21.5 \\
20.3 \\
1.09\end{array}$ \\
\hline Premixed with meal & $\begin{array}{l}7 \\
8 \\
9 \\
10 \\
11 \\
12 \\
\text { Mean } \\
\text { SE }\end{array}$ & $\begin{array}{c}13 \cdot 3 \\
9.1 \\
11 \cdot 0 \\
14.5 \\
30 \cdot 3 \\
14.3 \\
15.4 \\
3.09\end{array}$ & $\begin{array}{c}15.8 \\
14.3 \\
30.8 \\
20.5 \\
31.6 \\
16.0 \\
21.5 \\
3.18\end{array}$ & $\begin{array}{c}97 \cdot 9 \\
100 \cdot 1 \\
96 \cdot 4 \\
96 \cdot 0 \\
83.4 \\
97 \cdot 2 \\
95 \cdot 4 \\
2.52\end{array}$ & $\begin{array}{c}13 \cdot 4 \\
12 \cdot 3 \\
9.73 \\
12.9 \\
18 \cdot 3 \\
13.8 \\
13.4 \\
1.14\end{array}$ & $\begin{array}{c}15.9 \\
17 \cdot 3 \\
29.8 \\
19.0 \\
18.0 \\
15.5 \\
19.3 \\
2.17\end{array}$ \\
\hline $\begin{array}{l}\text { Significance of differenc } \\
\text { between procedures }\end{array}$ & & NS & NS & NS & $P<0.01$ & NS \\
\hline
\end{tabular}

*For details of procedures, see pp. 576-577. 

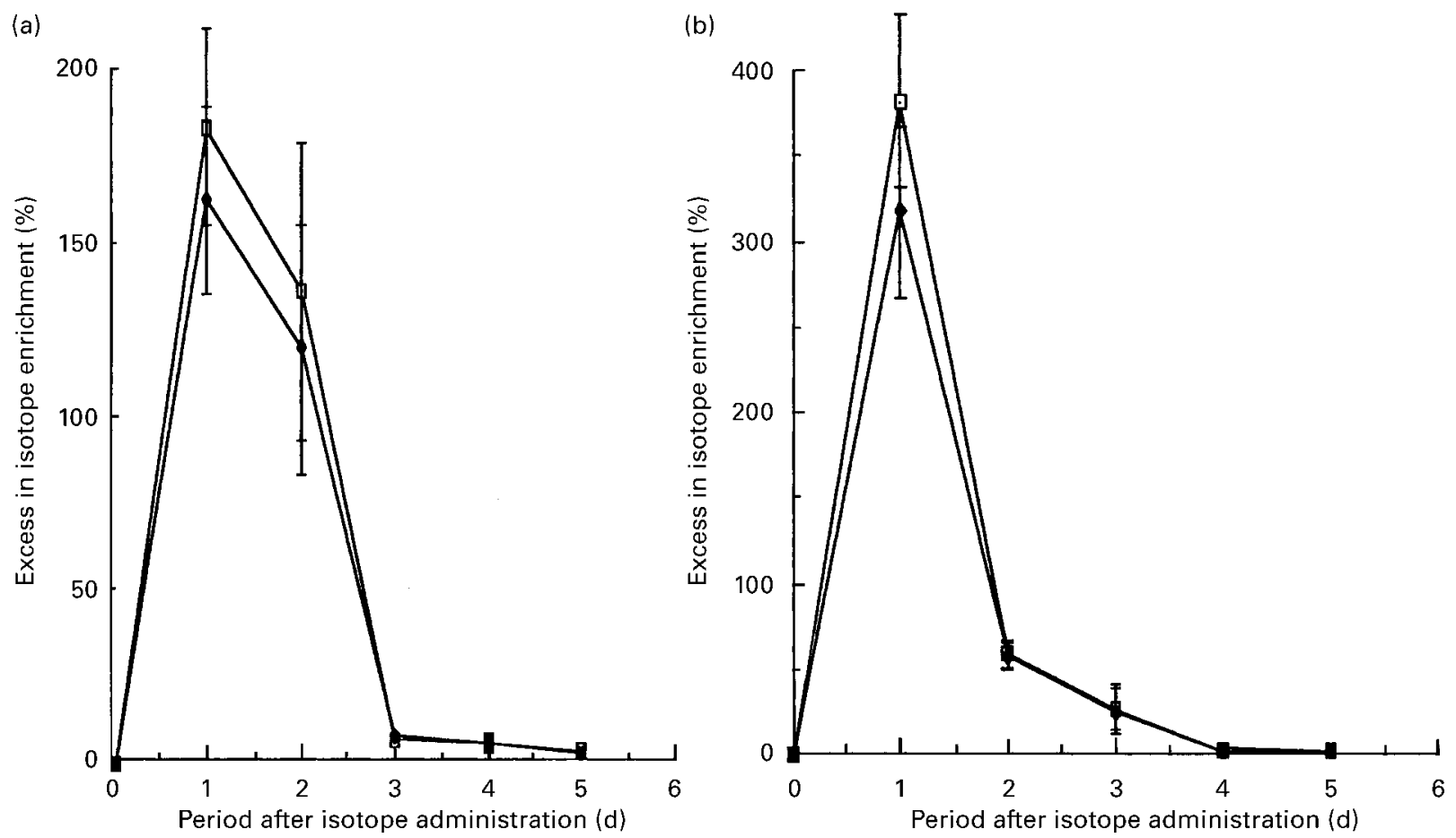

Fig. 2. Faecal isotope enrichment $\left({ }^{67} \mathrm{Zn}:{ }^{66} \mathrm{Zn}(\square)\right.$ and $\left.{ }^{65} \mathrm{Cu}:{ }^{63} \mathrm{Cu}(\bullet)\right)$ over $5 \mathrm{~d}$ after isotope administered orally (a) or premixed with a small meal (b) in rats given $0.15 \mathrm{mg}{ }^{67} \mathrm{Zn}(2.24 \mu \mathrm{mol})$ and $0.15 \mathrm{mg}{ }^{65} \mathrm{Cu}(2.31 \mu \mathrm{mol})$ and $1.0 \mathrm{mg}$ dysprosium $(6.15 \mu \mathrm{mol})$ after a $16 \mathrm{~h}$ fast. Faeces of each day were lyophilized, powdered and a subsample was mineralized and analysed by inductively-coupled plasma mass spectrometry for isotope-ratio measurements. For the $3 \mathrm{~d}$ pooled faecal sample, $20 \mathrm{mg} / \mathrm{g}$ faeces from the first $3 \mathrm{~d}$ were mixed, mineralized and analysed. For details of procedures, see pp. 576-577. For $3 \mathrm{~d}$ pooled faeces, faecal isotope enrichments were: (a) ${ }^{67} \mathrm{Zn} 115 \%$, ${ }^{65} \mathrm{Cu} 102 \%$; (b) ${ }^{67} \mathrm{Zn} 129 \%$, ${ }^{65} \mathrm{Cu} 114 \%$.

\section{Polyphenol study}

On the basis of the results of the preliminary study, a target dose of $0 \cdot 1 \mathrm{mg}{ }^{67} \mathrm{Zn}$ and $0 \cdot 1 \mathrm{mg}{ }^{65} \mathrm{Cu}$ with $0.5 \mathrm{mg}$ Dy were administered to each rat premixed with a small meal after a $16 \mathrm{~h}$ fast. Rat growth was not affected by any of the PP consumed for $6 \mathrm{~d}$ in the present study. Analysis of the $3 \mathrm{~d}$ faecal pools showed an isotope enrichment of $72 \%$ for ${ }^{67} \mathrm{Zn}$ and $67 \%$ for ${ }^{65} \mathrm{Cu}$ in the control group. The enrichment of ${ }^{67} \mathrm{Zn}$ and ${ }^{65} \mathrm{Cu}$ in the $0-36 \mathrm{~h}$ pooled urine samples averaged about 28 and $58 \%$ respectively for the control group. With the analytical performance of the ICP/MS instrument used in the present study, such high values for enrichment guarantee highly-reliable isotope-ratio measurements.

Table 2. Effect of polyphenol ingestion on apparent ${ }^{67} \mathrm{Zn}$ absorption with and without correction for faecal marker (dysprosium) in rats ${ }^{*}$ (Values are means with their standard errors for ten rats for the control group and eight rats for the other groups)

\begin{tabular}{|c|c|c|c|c|c|c|}
\hline \multirow[b]{2}{*}{ Treatment group } & \multicolumn{3}{|c|}{ Without correction } & \multicolumn{3}{|c|}{ With correction $†$} \\
\hline & $\begin{array}{l}\text { Ingested } \\
67 \mathrm{Zn}(\mu \mathrm{g})\end{array}$ & $\begin{array}{l}\text { Faecal excretion of } \\
{ }^{67} \mathrm{Zn}(\mu \mathrm{g} / 3 \mathrm{~d})\end{array}$ & $\begin{array}{l}\text { Absorption of } \\
{ }^{67} \mathrm{Zn}(\%)\end{array}$ & $\begin{array}{l}\text { Recovery of } \\
\text { faecal marker } \\
\text { Dy }(\%)\end{array}$ & $\begin{array}{c}\text { Faecal excretion of } \\
{ }^{67} \mathrm{Zn}(\mu \mathrm{g} / 3 \mathrm{~d})\end{array}$ & $\begin{array}{l}\text { Absorption of } \\
{ }^{67} \mathrm{Zn}(\%)\end{array}$ \\
\hline $\begin{array}{c}\text { Control: Mean } \\
\text { SE }\end{array}$ & $\begin{array}{r}87.4^{a} \\
0.69\end{array}$ & $\begin{array}{r}66 \cdot 1^{\mathrm{a}} \\
1.15\end{array}$ & $\begin{array}{r}24.3^{\mathrm{a}} \\
1.49\end{array}$ & $\begin{array}{r}96 \cdot 8^{\mathrm{a}} \\
3.54\end{array}$ & $\begin{array}{r}68 \cdot 3^{\mathrm{a}} \\
1.15\end{array}$ & $\begin{array}{r}21.8^{\mathrm{a}} \\
0.68\end{array}$ \\
\hline $\begin{array}{l}\text { Chlorogenic acid: Mean } \\
\text { SE }\end{array}$ & $\begin{array}{r}87.8^{\mathrm{a}} \\
0.57\end{array}$ & $\begin{array}{r}71.0^{\mathrm{a}} \\
1.30\end{array}$ & $\begin{array}{r}19 \cdot 1^{\mathrm{b}} \\
1.19\end{array}$ & $\begin{array}{r}96 \cdot 7^{\mathrm{a}} \\
4 \cdot 21\end{array}$ & $\begin{array}{r}73 \cdot 4^{\mathrm{a}} \\
1.30\end{array}$ & $\begin{array}{r}16 \cdot 4^{\mathrm{b}} \\
1.04\end{array}$ \\
\hline $\begin{array}{l}\text { Caffeic acid: Mean } \\
\text { SE }\end{array}$ & $\begin{array}{r}83.6^{\mathrm{a}} \\
3.43\end{array}$ & $\begin{array}{r}68.2^{\mathrm{a}} \\
3.97\end{array}$ & $\begin{array}{r}18.8^{\mathrm{b}} \\
1.79\end{array}$ & $\begin{array}{r}97 \cdot 0^{\mathrm{a}} \\
4.92\end{array}$ & $\begin{array}{r}70 \cdot 3^{\mathrm{a}} \\
3.97\end{array}$ & $\begin{array}{r}15 \cdot 9^{b} \\
1.34\end{array}$ \\
\hline $\begin{array}{c}\text { Catechin: Mean } \\
\text { SE }\end{array}$ & $\begin{array}{r}86 \cdot 9^{\mathrm{a}} \\
0.66\end{array}$ & $\begin{array}{r}68.7^{\mathrm{a}} \\
1.23\end{array}$ & $\begin{array}{c}20 \cdot 9^{\mathrm{ab}} \\
1.70\end{array}$ & $\begin{array}{r}96 \cdot 2^{\mathrm{a}} \\
5 \cdot 12\end{array}$ & $\begin{array}{r}71.4^{\mathrm{a}} \\
1.23\end{array}$ & $\begin{array}{c}17 \cdot 8^{\mathrm{ab}} \\
1.45\end{array}$ \\
\hline $\begin{array}{l}\text { Rutin: Mean } \\
\text { SE }\end{array}$ & $\begin{array}{r}75 \cdot 1^{\mathrm{b}} \\
0.11\end{array}$ & $\begin{array}{r}58 \cdot 6^{\mathrm{b}} \\
1 \cdot 17\end{array}$ & $\begin{array}{l}22 \cdot 0^{\mathrm{ab}} \\
1.56\end{array}$ & $\begin{array}{r}95.4^{\mathrm{a}} \\
3.89\end{array}$ & $\begin{array}{r}61 \cdot 4^{\mathrm{b}} \\
1.17\end{array}$ & $\begin{array}{c}18 \cdot 3^{\mathrm{ab}} \\
1.68\end{array}$ \\
\hline
\end{tabular}

\footnotetext{
a,b Mean values within the same column with unlike superscript letters were significantly different $(P<0.05)$.

${ }^{*}$ For details of procedures, see pp. 576-577.

†Calculated by dividing the amount of unabsorbed isotope by the percentage recovery of faecal marker in the faeces.
} 
Intestinal absorption of ${ }^{67} \mathrm{Zn}$ calculated on the basis of the $3 \mathrm{~d}$ pooled faeces without and with correction for the recovery percentage of faecal marker are shown in Table 2. Chlorogenic and caffeic acids significantly decreased the absorption of ${ }^{67} \mathrm{Zn}$ when compared with control group $(P<0.05)$ for both measured and corrected absorption values. However, catechin and rutin were without effect on ${ }^{67} \mathrm{Zn}$ absorption in the present study. The PP tested in the present study did not show any significant effect on ${ }^{65} \mathrm{Cu}$ absorption before or after correction for percentage recovery of the faecal marker, as shown in Table 3.

Table 4 shows the effect of PP ingestion on ${ }^{67} \mathrm{Zn}$ retention in rats. The determination of urinary elimination of ${ }^{67} \mathrm{Zn}$ during the $3 \mathrm{~d}$ after isotope administration indicated that the tested PP did not have any significant effect on urinary excretion of ${ }^{67} \mathrm{Zn}$. The results of the present study showed that only chlorogenic and caffeic acids significantly decreased the retention of ${ }^{67} \mathrm{Zn}$ in the rat.

The determination of ${ }^{65} \mathrm{Cu}$ urinary elimination indicated that the different PP tested did not show any significant effect on urinary excretion of ${ }^{65} \mathrm{Cu}$ (Table 4). These results show clearly that the PP compounds studied here did not exert any effect on either absorption or retention of ${ }^{65} \mathrm{Cu}$ in the rat under our experimental conditions.

\section{Discussion}

Before undertaking a large study on the effect of PP ingestion on $\mathrm{Zn}$ and $\mathrm{Cu}$ absorption, we carried out a preliminary experiment to validate our operating conditions. The chosen dose of isotope should be low enough not to disturb the mineral homeostasis, but high enough to permit reliable isotope-ratio measurements by ICP/MS. The faecal isotope enrichments obtained in the $3 \mathrm{~d}$ pooled faeces were more than $100 \%$ for both ${ }^{67} \mathrm{Zn}$ and ${ }^{65} \mathrm{Cu}$. Consequently, the doses of $0.15 \mathrm{mg}{ }^{67} \mathrm{Zn}$ or ${ }^{65} \mathrm{Cu}$ were sufficiently large to study the absorption of these metals in rats. However, administering such large doses is necessary for reliable urine isotope-enrichment measurements $(>10 \%)$, when mineral retention is measured. A target dose of $0.1 \mathrm{mg}$ ${ }^{67} \mathrm{Zn}$ (about $10 \%$ of intake) and $0.1 \mathrm{mg}{ }^{65} \mathrm{Cu}$ (about $50 \%$ of intake) was applied in our PP study. The preliminary study showed also that ${ }^{67} \mathrm{Zn}$ absorption was similar for both methods of administration of the isotope, whereas, ${ }^{65} \mathrm{Cu}$ absorption was higher when ${ }^{65} \mathrm{Cu}$ was given orally than when premixed with the diet. A similar finding was also obtained for $\mathrm{Mg}$ absorption in our laboratory (C Coudray, D Pepin, JC Tressol, J Bellanger and Y Rayssiguier, unpublished results). Thus, the measured mineral absorption from isotopes premixed with diet is more representative of that of the naturally-occurring mineral in the diet. For this reason, this method of administration was applied in the PP study. The preliminary study was also designed to determine whether Dy (a lanthanide element) can be used as a quantitative faecal marker for $\mathrm{Zn}$ and $\mathrm{Cu}$ absorption studies in rats. This approach is based on the assumption that these elements (lanthanides) are not absorbed. Several human studies have already reported that such elements could be useful as faecal markers (Schuette et al. 1993; FairweatherTait et al. 1997). In our study, ${ }^{67} \mathrm{Zn}$ and ${ }^{65} \mathrm{Cu}$, and Dy exhibited almost identical faecal excretion patterns. Consequently, ${ }^{67} \mathrm{Zn}$ or ${ }^{65} \mathrm{Cu}$ absorption values were the same from the 2nd day until day 5 of isotope administration, when this absorption was corrected for the percentage recovery of the faecal marker in the analysed faecal material. The results of this preliminary study showed clearly that Dy can be used as a quantitative faecal marker in the ${ }^{67} \mathrm{Zn}$ and ${ }^{65} \mathrm{Cu}$ absorption studies in the rat.

PP compounds tested in the present study were selected because they were commercially available and they resembled commonly-consumed PP. However, it is worth noting that there is a wide variety of PP in foods, and that the PP studied are only similar but not identical to food PP. Chlorogenic and caffeic acids are found in coffee, and many fruits, vegetables and legumes, and previous studies have shown their inhibitory effect on Fe absorption (Hurrell,

Table 3. Effect of polyphenol ingestion on apparent ${ }^{65} \mathrm{Cu}$ absorption with and without correction for faecal marker (dysprosium) in rats* (Values are means with their standard errors for ten rats for the control group and eight rats for the other groups)

\begin{tabular}{|c|c|c|c|c|c|c|}
\hline \multirow[b]{2}{*}{ Treatment group } & \multicolumn{3}{|c|}{ Without correction } & \multicolumn{3}{|c|}{ With correctiont } \\
\hline & $\begin{array}{l}\text { Ingested } \\
{ }^{65} \mathrm{Cu}(\mu \mathrm{g})\end{array}$ & $\begin{array}{l}\text { Faecal excretion } \\
{ }^{65} \mathrm{Cu}(\mu \mathrm{g})\end{array}$ & $\begin{array}{l}\text { Absorption of } \\
{ }^{65} \mathrm{Cu}(\%)\end{array}$ & $\begin{array}{c}\text { Recovery of } \\
\text { faecal marker } \\
\text { Dy }(\%)\end{array}$ & $\begin{array}{l}\text { Faecal excretion } \\
\text { of }{ }^{65} \mathrm{Cu}(\mu \mathrm{g} / 3 \mathrm{~d})\end{array}$ & $\begin{array}{l}\text { Absorption of } \\
{ }^{65} \mathrm{Cu}(\%)\end{array}$ \\
\hline $\begin{array}{c}\text { Control: Mean } \\
\text { SE }\end{array}$ & $\begin{array}{r}91 \cdot 1^{\mathrm{a}} \\
0.72\end{array}$ & $\begin{array}{r}76 \cdot 2^{\mathrm{a}} \\
0.69\end{array}$ & $\begin{array}{r}16 \cdot 3^{\mathrm{a}} \\
1.24\end{array}$ & $\begin{array}{r}96 \cdot 8^{\mathrm{a}} \\
3.54\end{array}$ & $\begin{array}{r}78.9^{a} \\
0.69\end{array}$ & $\begin{array}{r}13 \cdot 4^{\mathrm{a}} \\
0.84\end{array}$ \\
\hline $\begin{array}{c}\text { Chlorogenic acid: Mean } \\
\text { SE }\end{array}$ & $\begin{array}{r}91.5^{\mathrm{a}} \\
0.59\end{array}$ & $\begin{array}{r}79.0^{\mathrm{a}} \\
2 \cdot 07\end{array}$ & $\begin{array}{r}13 \cdot 7^{\mathrm{a}} \\
2 \cdot 11\end{array}$ & $\begin{array}{r}96 \cdot 7^{\mathrm{a}} \\
4 \cdot 21\end{array}$ & $\begin{array}{r}81 \cdot 5^{\mathrm{a}} \\
2 \cdot 07\end{array}$ & $\begin{array}{r}10.9^{\mathrm{a}} \\
1.07\end{array}$ \\
\hline $\begin{array}{l}\text { Caffeic acid: Mean } \\
\text { SE }\end{array}$ & $\begin{array}{r}87 \cdot 1^{\mathrm{a}} \\
3.58\end{array}$ & $\begin{array}{r}74 \cdot 1^{\mathrm{a}} \\
4 \cdot 26\end{array}$ & $\begin{array}{r}15 \cdot 3^{\mathrm{a}} \\
1 \cdot 74\end{array}$ & $\begin{array}{r}97.0^{\mathrm{a}} \\
4.92\end{array}$ & $\begin{array}{r}76 \cdot 5^{\mathrm{a}} \\
4 \cdot 26\end{array}$ & $\begin{array}{r}12 \cdot 2^{\mathrm{a}} \\
1 \cdot 32\end{array}$ \\
\hline $\begin{array}{c}\text { Catechin: Mean } \\
\text { SE }\end{array}$ & $\begin{array}{r}90.6^{\mathrm{a}} \\
0.69\end{array}$ & $\begin{array}{r}73.7^{\mathrm{a}} \\
1.24\end{array}$ & $\begin{array}{r}18.6^{\mathrm{a}} \\
1.43\end{array}$ & $\begin{array}{r}96 \cdot 2^{\mathrm{a}} \\
5 \cdot 12\end{array}$ & $\begin{array}{r}76.5^{\mathrm{a}} \\
1.24\end{array}$ & $\begin{array}{r}15 \cdot 6^{\mathrm{a}} \\
1.11\end{array}$ \\
\hline $\begin{array}{c}\text { Rutin: Mean } \\
\text { SE }\end{array}$ & $\begin{array}{r}78 \cdot 3^{\mathrm{b}} \\
0.12\end{array}$ & $\begin{array}{r}63.5^{\mathrm{a}} \\
1.62\end{array}$ & $\begin{array}{r}19 \cdot 3^{\mathrm{a}} \\
2 \cdot 06\end{array}$ & $\begin{array}{r}95 \cdot 4^{\mathrm{a}} \\
3.89\end{array}$ & $\begin{array}{r}66.1^{\mathrm{b}} \\
1.62\end{array}$ & $\begin{array}{r}15 \cdot 6^{\mathrm{a}} \\
1.75\end{array}$ \\
\hline
\end{tabular}

\footnotetext{
${ }_{\mathrm{a}, \mathrm{b}}$ Mean values within the same column with unlike superscript letters were significantly different $(P<0.05)$.

${ }^{*}$ For details of procedures, see pp. 576-577.

† Calculated by dividing the amount of unabsorbed isotope by the percentage recovery of faecal marker (Dy) in the faeces.
} 
1990; Gutnisky et al. 1992). Catechin, in the form of epigallocatechin gallate is the main constituent of green tea, and very abundant in our diet (proanthocyanides). Rutin, quercetin glycosylated to a carbohydrate, is a strong antioxidant and an important flavonoid present in many food items. PP levels in the diet used in the present study were $1 \mathrm{~g} / \mathrm{kg}$ for the four tested compounds, which corresponds to $20 \mathrm{mg} / \mathrm{d}$. The PP doses used in the present study correspond to a daily consumption of $4000 \mathrm{mg}$ PP for a $65 \mathrm{~kg}$ human subject, representing two to four times the nutritional daily intake. Although only the acute effect of PP was studied in the present study, PP were fed for $3 \mathrm{~d}$ before administrating ${ }^{65} \mathrm{Cu}$ - and ${ }^{67} \mathrm{Zn}$-labelled test meals to rats, to avoid the effect of previous meals. Indeed, it is known that diets fed before test meals can affect postprandial mineral absorption (Garcia-Lopez et al. 1990).

The present results indicated that acute ingestion of chlorogenic or caffeic acids significantly decreased ${ }^{67} \mathrm{Zn}$ absorption in rats, whereas they were without effect on ${ }^{65} \mathrm{Cu}$ absorption in rats. However, neither catechin nor rutin ingestion significantly affected ${ }^{65} \mathrm{Cu}$ or ${ }^{67} \mathrm{Zn}$ absorption under our experimental conditions.

This is the first time that the effect of these phenolic compounds on the absorption of essential trace elements has been studied using the stable-isotope approach. The observed decreases in ${ }^{67} \mathrm{Zn}$ absorption reached $25 \%$ in rats receiving chlorogenic acid and $27 \%$ in those receiving caffeic acid. Chlorogenic acid is a phenolic acid, an ester of caffeic acid and quinic acid, occurring in a variety of fruits and vegetables. In fact, chlorogenic acid exists in several chemical forms, the one used in the present study, caffeoyl-quinic acid (the commercially-available chlorogenic acid), being the most common form in coffee. Chlorogenic acid has been reported previously to exert an inhibitory action on intestinal $\mathrm{Fe}$ absorption in rats (Brown et al. 1990; Gutnisky et al. 1992). Further, Morck et al. (1983) demonstrated that coffee inhibited Fe absorption in a concentration-dependent fashion in human subjects.

Our results showed that acute ingestion of catechin is without significant effect on ${ }^{67} \mathrm{Zn}$ absorption or ${ }^{65} \mathrm{Cu}$ absorption in rats. In the present study, the effect of catechin on $\mathrm{Zn}$ absorption was less than that of chlorogenic or caffeic acids. Since catechin also contains catechol groups, an explanation other than the chemical structure per se may be found for this difference. A possible explanation is that the insolubility of the catechin molecule in water prevents formation of a complex between the catechol group of catechin and the mineral ions in the gastrointestinal lumen (Spencer et al. 1988). Previous studies have shown that tea consumption (rich in catechin derivatives) can impair trace element absorption, particularly $\mathrm{Fe}$, in human subjects and animals (Disler et al. 1975), and Fairweather-Tait \& Piper (1991) confirmed a previous report that long-term ingestion of tea impairs $\mathrm{Fe}$ status in rats (Brown et al. 1990), but Brune et al. (1989) reported no effect of catechin on Fe absorption in man. The effect of catechin on $\mathrm{Zn}$ or $\mathrm{Cu}$ absorption is still unclear. Greger \& Lyle (1988) reported that tea or catechin ingestion increased tissue $\mathrm{Zn}$ and $\mathrm{Cu}$ levels in rats, but Record et al. (1996) observed that absorption of $\mathrm{Fe}, \mathrm{Cu}$ and $\mathrm{Zn}$ was not affected by the green or black tea or crude green tea extract in rats. 
Flanagan et al. (1985) reported that the ingestion of tea with a single meal had no effect on absorption of ${ }^{65} \mathrm{Zn}$ in human subjects. However, Ganji \& Kies (1994) showed a small but not statistically significant adverse effect of tea consumption on $\mathrm{Zn}$ bioavailability in their subjects.

The present study showed that acute ingestion of rutin, the precursor of quercetin, was without effect on ${ }^{67} \mathrm{Zn}$ or ${ }^{65} \mathrm{Cu}$ absorption. The result obtained here can be explained in a number of ways. First, rutin has the lowest solubility of the PP studied and thus is less available for absorption. Second, rutin may be less efficient in its ability to chelate minerals than the other PP investigated. We have not found any published values for its stability constants with these minerals. Finally, the low molar ratio of rutin: minerals in the diet may be also responsible for this observed effect.

In conclusion, the findings of the present study are very interesting from a nutritional point of view. Not only can PP decrease non-haem-Fe absorption, but they can also negatively affect $\mathrm{Zn}$ absorption in the rat. ${ }^{67} \mathrm{Zn}$ absorption was decreased by $25 \%$ in rats receiving chlorogenic or caffeic acid. This negative effect on Zn absorption should thus be considered seriously in populations consuming diets consisting primarily of plant foods. Such diets contain a considerable amount of dietary fibre and PP which may have a considerable effect on mineral bioavailability. Human studies are needed to confirm these rat studies.

\section{Acknowledgements}

The authors would like to thank Volvic Centre for Research on Trace Elements (Danone, France) for the financial support. They also thank Augustin Scalbert for helping in the discussion and Richard Taylor for reading the manuscript. They also gratefully acknowledge the statistical assistance of Jean Vernet and the technical assistance of Claudine Lab and Elyett Gueux.

\section{References}

American Institute of Nutrition (1977) Report of the American Institute of Nutrition ad hoc committee on standards for nutritional studies. Journal of Nutrition 107, 1340-1348.

Arnaud J, Chappuis P, Jaudon MC \& Bellanger J (1993) Marqueurs biologiques nutritionnels des carences en zinc, cuivre et sélénium (Biological nutritional markers of deficiencies in zinc, copper and selenium). Annals de Biologie Clinique 51, 589-604.

Brown RC, Klein A, Simmons WK \& Hurrell RF (1990) The influence of Jamaican herb teas and other polyphenol-containing beverages on iron absorption in the rat. Nutrition Research 10, 342-353.

Brune M, Rossander L \& Hallberg L (1989) Iron absorption and phenolic compounds; importance of different phenolic structures. European Journal of Clinical Nutrition 43, 547-558.

Cook JD, Reddy MD \& Hurrell RF (1995) The effect of red and white wine on nonheme-iron absorption in humans. American Journal of Clinical Nutrition 61, 800-804.

Cook NC \& Samman S (1996) Flavonoids: Chemistry, metabolism, cardioprotective effects and dietary sources. Journal of Nutritional Biochemistry 7, 66-76.

Coudray C \& Fairweather-Tait S (1988) Do oligosaccharides affect intestinal absorption in humans? American Journal of Clinical Nutrition (In the press).
Coudray C, Pépin D, Tressol JC, Bellanger J \& Rayssiguier Y (1997) Study of magnesium bioavailability using stable isotopes and the inductively-coupled plasma mass spectrometry technique in the rat: single and double labelling approaches. British Journal of Nutrition 77, 957-970.

De Bièvre P \& Taylor PDP (1993) Table of isotopic composition of the elements. International Journal of Mass Spectrometry Ion Process 123, 149-166.

Disler PB, Lynch SR, Charlton RW, Torrance JD, Bothwell TH, Walker RB \& Mayet F (1975) The effect of tea on iron absorption. Gut 16, 193-200.

EEC (1986) Guidelines for the Use of Experimental Animals. L358-86/609/EEC. Brussels: Commission of European Community.

Fairweather-Tait SJ, Minihane AM, Eagles J, Owen L \& Crews HM (1997) Rare earth elements as non-absorbable fecal markers in studies of iron absorption. American Journal of Clinical Nutrition 65, 970-976.

Fairweather-Tait SJ \& Piper Z (1991) The effect of tea on iron and aluminium metabolism in the rat. British Journal of Nutrition 65, 61-68.

Flanagan PR, Cluett J, Chamberlain MJ \& Valberg LS (1985) Dual-isotope method for determination of human zinc absorption: the use of a test meal of turkey meat. Journal of Nutrition 115, 111-122.

Gabrielli GB \& De Sandre G (1995) Excessive tea consumption can inhibit the efficacy of oral iron treatment in iron-deficiency anemia. Haematologica 80, 518-520.

Ganji V \& Kies CV (1994) Zinc bioavailability and tea consumption: study in healthy humans consuming self-selected and laboratory-controlled diets. Plant Foods for Human Nutrition 46, 267-276.

Garcia-Lopez JS, Erdman JW \& Sherman AR (1990) Iron retention by rats from casein-legume test meals: Effect of tannin level and previous diet. Journal of Nutrition 120, 760-766.

Greger JL \& Lyle BJ (1988) Iron, copper and zinc metabolism of rats fed various levels and types of tea. Journal of Nutrition 118, $52-60$.

Gutnisky A, Rizzo N, Castro ME \& Garbossa G (1992) The inhibition action of chlorogenic acid on the intestinal iron absorption in rats. Acta Physiologica et Pharmacologica Latinoamericana 42, 139-146.

Hertog MGL \& Hollman PCH (1996) Potential health effects of the dietary flavonol quercetin. European Journal of Clinical Nutrition 50, 63-71.

Hurrell RF (1990) The influence of polyphenol-containing beverages on iron absorption. Proceedings of XVth International Meeting on Polyphenols, Strasbourg, vol. 15, pp. 268-274.

Janghorbani M \& Ting BTG (1990) Stable isotope methods for studies of mineral/trace element metabolism. Journal of Nutritional Biochemistry 1, 4-19.

McDonald M, Mila I \& Scalbert A (1996) Precipitation of metal ions by plant polyphenols: optimal conditions and origin of precipitation. Journal of Agricultural and Food Chemistry 44, 599-606.

Morck TA, Lynch SR \& Cook JD (1983) Inhibition of food iron absorption by coffee. American Journal of Clinical Nutrition 37, 416-420.

Record IR, McInerney JK \& Dreosti IE (1996) Black tea, green tea, and tea polyphenols: effects on trace element status in weaning rats. Biological Trace Element Research 5, 27-43.

Reddy NR, Pierson MD, Sathe SK \& Salunkhe DK (1985) Dry bean tannins: a review of nutritional implications. Journal of the American Oil Chemistry Society 62, 541-549.

Schuette SA, Janghorbani M, Young VR \& Weaver CM (1993) Dysprosium as a nonabsorbable marker for studies of mineral absorption with stable isotope tracers in human subjects. Journal of the American College of Nutrition 12, 307-312. 
Spencer CM, Gai Y, Martin R, Gaffney SH, Goulding PN, Magnolato D, Lilley TH \& Haslam E (1988). Polyphenol complexation. Some thoughts and observations. Phytochemistry 27, 2397-2409.

Statistical Analysis Systems (1989) SAS Users Guide. Statistics, 5th ed., pp. 891-996. Cary, NC: SAS Institute.

Tuntawiroon M, Sritongkul N, Brune M, Rossander-Hultén L,
Pleehachinda R, Suwanik R \& Hallberg L (1991) Dosedependent inhibitory effect of phenolic compounds in foods on non heme-iron absorption in men. American Journal of Clinical Nutrition 53, 554-557.

Veillon C \& Patterson KY (1996) Trace elements in a commercial freeze-dried human urine reference material. Analyst 121, 983-985. 